\title{
THE DISTRIBUTION OF CASE RECOGNITION BEHAVIOUR IN TEN FAMILIES OF CADDIS LARVAE (TRICHOPTERA)
}

\author{
BY DOROTHY MERRILL \\ Department of the Biological Sciences, Smith College, Northampton, Mass. 01060 and \\ the University of Michigan Biological Station
}

Most students of animal behaviour are familiar with the case-building behaviour of caddis larvae and know that case-building activity can generally be induced if one removes a larva from its case and provides it with building materials. Very little has been written, however, about the capacity of a larva to re-enter a case when the evicted larva is allowed to come in contact with the exterior of its case.

Alverdes (1925) described the reactions of Limnephilus flavicornis larvae to their cases, noting that the individual larvae differed greatly in their Findencapacität, sometimes remaining outside for hours. Case entry always occurred head-first in his observations. Davis (1934) mentioned larvae which had taken possession of cases not made by themselves, thus implying some degree of case recognition. Merrill (1964) noted the poor capacity of three limnephilid species for re-entering cases, in contrast to the rapid entry of the phryganeid larva Ptilostomis, and ventured to state that the limnephilid species lacked case recognition, i.e. a capacity for re-entering its case (or a case of similar size built by a member of the same species) with a predictable set of behaviour patterns.

In order to determine the extent of case recognition among trichopteran larvae, a standardized procedure was designed and a series of tests was undertaken on as many different species of caddis larvae as possible. The results are presented in this paper. A preliminary report has been published (Merrill \& Shaw 1966).

\section{Materials and Methods \\ Collection and Maintenance of Larvae}

Larvae were collected from a variety of aquatic habitats in western Massachusetts and northern Michigan. Collecting in the latter area was limited to the summer months of 1965, 1966 and 1968. The work in Massachusetts extended through the summer of 1967 and the ensuing academic year. The animals were transported to the laboratory and maintained in fingerbowls of aerated tap water, usually at room temper- ature $\left(20\right.$ to $\left.25^{\circ} \mathrm{C}\right)$. Larvae collected from cold waters were maintained in the refrigerator if previous experience with the species suggested a low tolerance to room temperature. Plant material from the habitats was placed in the fingerbowls with the larvae.

Keys by Ross (1944), Flint (1960), and Wiggins (1960) permitted identification of the larvae to genus and sometimes to species. If the animals subsequently pupated, they were reared to the adult stage in order to verify species identification. I tested 24 genera, representing 10 families and (probably) 31 species.

\section{Testing for Case Recognition}

Encased larvae were isolated in individual stender dishes containing tap water at the temperperature at which the animals had been maintained. Eviction of a larva from its case involved lifting the case from the water, carefully removing the silk membrane or any other structures narrowing the posterior opening, and gentle pushing of the larva from the posterior end with a blunt rod of appropriate diameter, varying in size from a 4-mm glass rod to headless minuten pins. The naked larva was placed in the stender dish and observed for a brief time. Some larvae tended to grasp the end of the abdomen with their legs and to remain in this curled-up position for several seconds or even minutes.

When the larva began to move about, the case was placed in the container, care being taken to prevent the trapping of air bubbles in the case. Since a larval encounter with most objects evokes grasping of the object with the prothoracic legs and simultaneous investigation with the mouthparts, a stopwatch was started when this reaction occurred on contact with the case.

If the larva did not enter the case on its initial contact and subsequently lost contact with the case, the case was moved with forceps to position it where it could quickly be encountered again by the larva. Every effort was made to induce contacts at the middle of the case 
with the larval path approximately perpendicular to the case axis. A larva was allowed thirty contacts or $30 \mathrm{~min}$, whichever came first, before being recorded as a non-entry. If step 4 of a recognition response (see below) was in progress at $30 \mathrm{~min}$, the time was extended until the larva either entered the case or ceased to show activity likely to result in case entry.

Non-entries were removed from the water and inserted in their cases tail first. In spite of larval resistance, one could generally get the case over the terminal segments and could then induce the larva to back in with some gentle prodding at the anterior end.

If the larva entered the case during the test, the time and the number of contacts were noted and also the manner of entry. Since a larva entering a tapered case head-first often had difficulty in getting the entire abdomen into the case, I arbitrarily chose to count the animal inside when only two abdominal segments remained exposed. For larvae which backed into the case, the timer was stopped when the entire abdomen was inside, leaving only the head and thorax exposed.

Samples of not less than eight larvae of each species were used in these tests if at least that many had been collected. Most larvae were given two trials and sometimes more. Periods of several hours to 1 or 2 days intervened between successive tests of the same larva.

Overhead lighting was continually present during the tests. When observations were made through a dissecting microscope with side illumination, no changes in larval behaviour were seen when the lamp was switched on or off or was moved to a different position. For lengthy observations, the lamp was switched off to minimize heating of the water.

\section{Special Techniques}

1. Removal of Helicopsyche larvae from their cases, which are built in the form of spiral snail shells, could not be effected by the standard procedure. Instead, the larvae were anaesthetized in 3 per cent cther in tap water for several minutes until no reactions could be elicited by tactile stimulation. The larva was then grasped with forceps behind the head and gently shaken. This action sometimes freed the larva from the case.

If this procedure was unsuccessful, the case was placed spire up on the stage of a dissecting microscope, and the spire was gently broken away with watchmakers forceps, beginning at the tip. With care, one could generally avoid damaging the animal when breaking the case wall in the region of the animal's posterior end. Then it was possible to loosen the anal hooks and push the animal from the case. Although this procedure damaged one side of the case, the portion surrounding the opening remained intact, and this part was exposed to the larva in the recognition tests. The tests were delayed until the larvae appeared to have recovered from anaesthesia, and observations were extended for up to $2 \mathrm{hr}$. Damaged animals were not used.

2. Turbulence testing. Work with Glossosoma larvae, which are always associated with rapid currents (Betten 1934), suggested that these larvae might show a better response in turbulent water than in still water. In fact, the larvae generally left their cases when kept in still water or in gently aerated water, especially at room temperature. Therefore, after a test by the standard procedure, the larvac were subjected to turbulence created by vigorous aeration of the water in the stender dish. Either intermittent or continuous turbulence was applied for a period of up to $10 \mathrm{~min}$. Only Glossosoma and Neophylax larvae were tested by this additional method.

\section{Results}

\section{The Nature of the Recognition Response}

Larvae entered their cases by two methodshead-first, which was the more common, and backing, which was seen only in the genera Leptocella and Helicopsyche. These methods are described below for two species whose caseentry patterns have been recorded and presented on motion picture film (Merrill \& Shaw 1967).

Ptilostomis semifasciata provides a typical example of head-first entry in terms of the motions used. After the initial grasping of the case, the larva (1) oriented itself parallel to the longitudinal axis and (2) began crawling toward one end of the case. Upon reaching the end, the larva (3) bent its head ventrad and appeared to investigate the opening with its mouth parts. If the opening was the anterior one and therefore clearly large enough for the animal, the larva generally (4) inserted its prothoracic legs and began to pull itself into the case. If the opening was the posterior one, the larva sometimes tried to crawl in at this end and generally succeeded, since Ptilostomis cases are usually wide enough for entry at both ends. Sometimes, however, investigation of the posterior opening was followed by the larva's turning around, crawling to the anterior opening, and entering there. Occasionally, a larva would 
reverse itself in this fashion two or three times before entering.

Leptocella diarina, which always entered its case by backing, began with the same motions noted above, through step 3 . During these procedures, particularly step 2 , an additional behaviour pattern was noted-the end of the abdomen was bent ventrad in a hooklike fashion and then straightened out, this sequence occurring every few seconds. After investigation of the mouth of the case, the larva reversed its direction and began crawling toward the posterior end, continuing to hook and straighten its abdomen. In time, the hooking of the abdomen usually resulted in the anal hooks catching in the mouth of the case, whereupon the larva worked its way inside by stretching the tip of the abdomen, gaining a new purchase on the inner walls of the case with its anal hooks, and then shortening the abdomen to pull more of the body inside. If the larva failed to catch the opening with its abdomen on its first attempt, it reversed its direction, returned to the anterior end, and repeated the procedure.

Observations of other species revealed some minor variations in entry patterns. In contrast to Ptilostomis and other phryganeids, most tubebuilding larvae seemed to have little space for manoeuvring as they crawled into their cases head-first. The two posterior pairs of legs had to be directed posteriorly and held against the body in order to get them inside. If the legs were not manipulated in this manner, they generally hit the rim of the case and hindered the animal's progress. Tindall (1960) reported that Triaenodes bicolor uses both anterior pairs of legs to pull itself into the case while the metathoracic legs are held against the body. Once the non-phryganeid larva was inside the case, the procedure of turning around to face the antcrior opening was very tedious, again in contrast to the phryganeids, which can turn around quickly.

Among Leptocella larvae that entered by backing there was some variation in the amount of activity in the abdomen. In the Glossosomatidae and Hydroptilidae, respectively designated by Ross (1964) as saddle-case and pursecase builders, step 1 was not evident in the recognition response.

Some larvae showed a response pattern as far as step 4 for Ptilostomis, but seemed unable to pull themselves inside. This was particularly observed in Brachycentrus larvae, whose large, robust meso- and meta-thoracic legs were impossible to squeeze past the opening unless they were held back against the body. Whenever this occurred during the testing procedure, the response was noted even though the trial had to be counted as a non-entry.

Among larvae that did not enter their cases, other behaviour patterns were frequently observed such as: (1) long pauses in crawling along the case; (2) reaching outward with the prothoracic legs; (3) frequent reversal of direction other than at the ends of the case; (4) crawling off the case, thereby losing contact. A few larvae even showed case-building activity, using bits of detritus from the case.

\section{The Distribution of the Reponse among the Trichoptera}

Table I presents the results of the testing procedure. Only the initial test on each larva is included here; results of multiple testing will be incorporated into the discussion that follows. The larvae are divided into three categories: (1) those that entered the case as a result of the first contact, even though entry may have required several minutes; (2) those that lost contact at least once, but entered on a subsequent contact; (3) those that did not enter in $30 \mathrm{~min}$ or thirty contacts. Means and standard deviation of entry times are presented for the first group. Only the means are given for the entry times and the number of contacts in the second group,

In every family represented, at least some of the larvae entered their cases under the test conditions. When second and third trials were run, the results usually did not differ significantly from the results of the first trials. In no instance was there a significant reduction in entry time to suggest learning. In a few instances, larvae performed less well on later trials, with a larger percentage of non-entries.

It is noteworthy that of the ten families, only the Phryganeidae showed a consistently strong capacity for case entry. This is indicated in the Table not only by the high percentage of individuals entering on first contact, but also by the speed of entry. In addition to the three phryganeid species listed in Table I, I have observed case entry at comparable speeds in Agrypnia vestita, Phryganea sp., Banksiola smithi, Ptilostomis postica, and $P$. semifasciata, but the times were not measured with a stopwatch.

The only phryganeids observed to have entry times averaging more than $10 \mathrm{sec}$ were young Banksiola crotchi larvae, whose cases were bushy like those described by Wesenberg-Lund (1911) (cf. Balduf 1939) for young larvae of Phryganea grandis. Four first instars entered their cases in 
Table I. The Response of Trichopteran Larvae to Contact with Their Cases Following Eviction

\begin{tabular}{|c|c|c|c|c|c|c|c|c|c|}
\hline Larval classification & $\begin{array}{l}\text { No. of } \\
\text { larvae } \\
\text { tested }\end{array}$ & $\begin{array}{l}\text { (1) } \% \\
\text { entering } \\
\text { on 1st } \\
\text { contact }\end{array}$ & \multicolumn{3}{|c|}{$\begin{array}{l}\text { Average } \\
\text { time (min) } \\
\bar{x} \pm S D\end{array}$} & $\begin{array}{l}\text { (2) } \% \\
\text { entering } \\
\text { later } \\
\text { contact }\end{array}$ & $\begin{array}{l}\text { Av. no. } \\
\text { of } \\
\text { contacts }\end{array}$ & $\begin{array}{l}\text { Av. time } \\
\text { (min) }\end{array}$ & $\begin{array}{c}\text { (3) } \% \\
\text { not } \\
\text { entering }\end{array}$ \\
\hline $\begin{array}{l}\text { Glossosomatidae } \\
\text { Glossosoma sp. }\end{array}$ & $\begin{array}{r}9 \\
24\end{array}$ & $\begin{array}{r}0 \\
67\end{array}$ & 1.6 & \pm & 1.4 & $\begin{array}{l}22 \\
29\end{array}$ & $\begin{array}{l}2 \cdot 5 \\
7 \cdot 0\end{array}$ & $\begin{array}{r}12 \cdot 5 \\
5 \cdot 5\end{array}$ & $\begin{array}{r}78 \\
4\end{array}$ \\
\hline $\begin{array}{l}\text { Hydroptilidae } \\
\text { Ochrotrichia sp. } \\
\text { Neotrichia sp. }\end{array}$ & $\begin{array}{l}3 \\
1\end{array}$ & $\begin{array}{l}100 \\
100\end{array}$ & $\begin{array}{l}1 \cdot 3 \\
0 \cdot 25\end{array}$ & \pm & & & & & \\
\hline $\begin{array}{l}\text { Brachycentridae } \\
\text { *Brachycentrus americanus }\end{array}$ & 24 & 38 & $7 \cdot 2$ & \pm & $9 \cdot 1$ & 4 & 3 & 17 & 58 \\
\hline $\begin{array}{l}\text { Phryganeidae } \\
\text { Ptilostomis pr. ocellifera } \\
\text { Oligostomis sp. } \\
\text { * Banksiola crotchi }\end{array}$ & $\begin{array}{r}11 \\
8 \\
10\end{array}$ & $\begin{array}{r}100 \\
100 \\
90\end{array}$ & $\begin{array}{l}0 \cdot 11 \\
0 \cdot 11 \\
0 \cdot 11\end{array}$ & $\begin{array}{l} \pm \\
\pm \\
\pm\end{array}$ & $\begin{array}{l}0.03 \\
0.03 \\
0.04\end{array}$ & 10 & 2 & 0.5 & \\
\hline 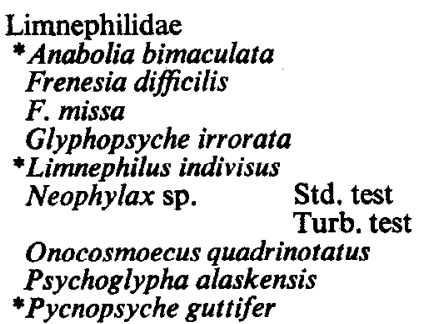 & $\begin{array}{r}7 \\
5 \\
8 \\
6 \\
10 \\
8 \\
8 \\
5 \\
15 \\
15\end{array}$ & $\begin{array}{c}86 \\
0 \\
50 \\
100 \\
(60 \% \text { entere } \\
\\
80 \\
73 \\
20\end{array}$ & $\begin{array}{r}5.6 \\
11.1 \\
1.6 \\
\text { d; no. }\end{array}$ & $\begin{array}{c} \pm \\
\pm \\
\pm \\
\text { of cor }\end{array}$ & $\begin{array}{l}4 \cdot 0 \\
7 \cdot 4 \\
0.6 \\
\text { ntacts }\end{array}$ & 20 & ; $13 \cdot 3 \pm$ & $\begin{array}{l}28 \cdot 5 \\
8 \cdot 4 \mathrm{~min})\end{array}$ & $\begin{array}{r}14 \\
80 \\
50 \\
40 \\
100 \\
100 \\
\\
\\
67\end{array}$ \\
\hline $\begin{array}{l}\text { Lepidostomatidae } \\
\text { * Lepidostoma togatum }\end{array}$ & 16 & 38 & $3 \cdot 1$ & \pm & $4 \cdot 8$ & 6 & 8 & $2 \cdot 5$ & 56 \\
\hline $\begin{array}{l}\text { Odontoceridae } \\
\text { Psilotreta sp. }\end{array}$ & 15 & 27 & 0.88 & \pm & 0.09 & 73 & $4 \cdot 0$ & $2 \cdot 9$ & \\
\hline $\begin{array}{l}\text { Molannidae } \\
\text { Molanna sp. (Mass. stream) } \\
\text { Molanna sp. (Mich. lake) }\end{array}$ & $\begin{array}{r}6 \\
10\end{array}$ & $\begin{array}{r}0 \\
40\end{array}$ & 4.0 & \pm & 2.8 & $\begin{array}{l}50 \\
30\end{array}$ & $\begin{array}{r}16 \cdot 7 \\
7 \cdot 7\end{array}$ & $\begin{array}{l}9 \cdot 5 \\
8 \cdot 3\end{array}$ & $\begin{array}{l}50 \\
30\end{array}$ \\
\hline $\begin{array}{l}\text { Helicopsychidae } \\
\text { *Helicopsyche borealis }\end{array}$ & 7 & 57 & Indiv & idual & times & es: $3,4,75$ & $105 \mathrm{~min}$ & & 43 \\
\hline $\begin{array}{l}\text { Leptoceridae } \\
{ }^{*} \text { Triaenodes injusta } \\
{ }^{*} \text { T. nox } \\
\text { Oecetis cinerascens } \\
{ }^{*} \text { Mystacides sepulchralis } \\
\text { Athripsodes alagmus } \\
{ }^{*} \text { Leptocella diarina } \\
{ }^{*} \text { L. exquisita } \\
{ }^{*} \text { L. candida } \\
{ }^{*} \text { L. pavida } \\
\text { L. albida }\end{array}$ & $\begin{array}{r}18 \\
14 \\
8 \\
8 \\
6 \\
10 \\
19 \\
6 \\
12 \\
4\end{array}$ & $\begin{array}{r}38 \\
16 \\
90 \\
95 \\
100 \\
42 \\
75\end{array}$ & $\begin{array}{c}1 \cdot 4 \\
1 \cdot 4 \\
3 \cdot 2 \\
11 \\
4 \cdot 9 \\
6 \cdot 0 \\
6 \cdot 2 \\
3 \cdot 0 \\
4 \cdot 1\end{array}$ & $\begin{array}{l} \pm \\
\pm \\
\pm \\
\pm \\
\pm \\
\pm \\
\pm \\
\pm\end{array}$ & $\begin{array}{l}1 \cdot 3 \\
1 \cdot 5 \\
2 \cdot 5 \\
5 \cdot 0 \\
5 \cdot 4 \\
4 \cdot 5 \\
1 \cdot 6 \\
1 \cdot 2\end{array}$ & $\begin{array}{r}25 \\
10 \\
5\end{array}$ & $\begin{array}{l}4 \cdot 0 \\
2 \\
2 \\
4 \cdot 5 \\
5\end{array}$ & $\begin{array}{c}1 \cdot 8 \\
4 \cdot 8 \\
9 \\
25 \\
\\
3 \cdot 4 \\
8 \cdot 4\end{array}$ & $\begin{array}{r}100 \\
37 \\
84\end{array}$ \\
\hline
\end{tabular}

* Species identification verified by rearing

$1.50 \pm 0.18 \mathrm{~min}$, while three second instars averaged $0.30 \pm 0.13 \mathrm{~min}$ for entry. Trimming off the projecting material in the cases to convert them to spiral cases resembling those of the mature larvae resulted in abnormal responses and increased entry time.

Although 100 per cent entry on first contact is indicated for the Hydroptilidae tested, the sample is too small to permit generalization.

In other families, there were large differences 
between species. The limnephilids ranged from 100 per cent entry in Glyphopsyche to zero recognition in Neophylax. The latter genus has the peculiar habit of estivating during the summer (Ross 1944), and it should be noted here that the larvae represented in Table I were collected and tested as active larvae. Similarly, the leptocerids varied in their responses from good recognition in Triaenodes and some Leptocella species to the poor performances of Oecetis and Athripsodes. Interestingly, Triaenodes larvae from dextral cases responded as readily to sinistral cases as to their own, and vice versa.

Glossosoma larvae responded to their cases much more readily under conditions of turbulence than in quiet water. As noted above, turbulence appears to be a necessary condition for keeping these larvae in their cases. In contrast, Neophylax, which is generally found in the same rapid stream habitats as Glossosoma, showed no recognition response under either condition and also showed no tendency to leave its case.

Results of multiple trials on Brachycentrus and Lepidostoma larvae suggest that there is considerable variation among individuals within a species with regard to case recognition. Figure 1 indicates the number of larvae in each species showing $0,1,2$, or 3 recognition responses in three trials. The twenty-two Brachycentrus larvae are found concentrated at the ends of the histogram, i.e. there was a strong probability that if a larva showed a recognition response on its first trial, it would do so on successive trials, while a failure to show a recognition response on the first trial would probably be followed by other failures. The recognition responses include attempts to enter a case without success in addition to actual case entry.

The sixteen Lepidostoma larvae had a slightly different distribution. There is again a group of larvae that showed a recognition response on each of their three trials, but a second maximum is seen for those that responded only once in their three trials. Only one larva failed to show a recognition response on any of its three trials. This sample of larvae might therefore be separated into two groups representing good recognition and poor recognition whereas the Brachycentrus sample is divided between good recognition and no recognition.

\section{The Occurrence of Backing}

It was stated earlier that backing was encountered in only two genera, Helicopsyche

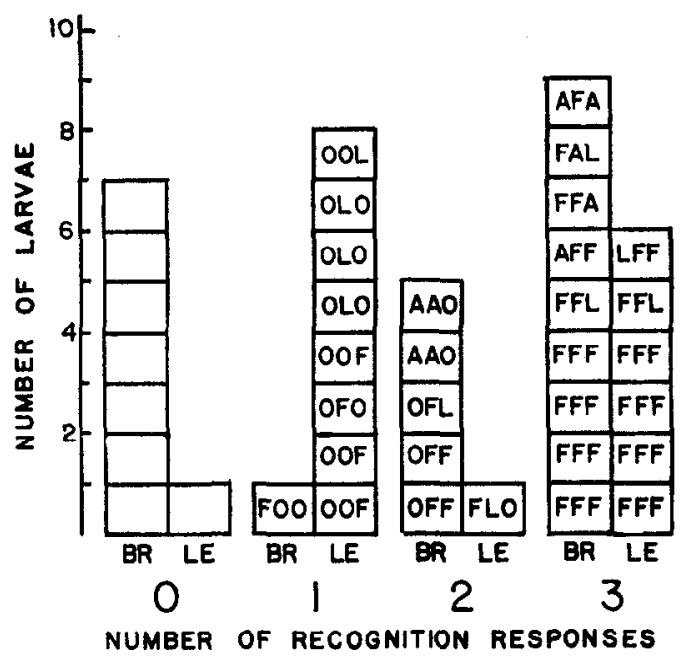

Fig. 1. Histogram representing numbers of Brachycentrus and Lepidostoma larvae $v$. number of trials out of three in which they showed a recognition response. Blocks represent individual larvae. Symbols in blocks indicate, in order of occurrence, the results of the three trials for larvae showing one or more recognition responses. A: attempted entry without success; F: entered case on first contact; $L$ : entered on later contact; $O$ : no recognition response during trial; BR: Brachycentrus; LE: Lepidostoma.

and Leptocella. There seems to be no previous report of backing in Helicopsyche. Backing by Leptocella diarina was first noted by Merrill \& Shaw (1967). The four Helicopsyche larvae that entered their cases in the tests reported in Table I all did so by backing. Among the six Leptocella species tested, there was variation in the extent to which backing was used for case entry. Table II presents the results of multiple testing on these six species plus a single larva which matched the description of Leptocella species a (Ross 1944).

Wherever both the head-first and backing methods were used by members of a species, some of the larvae exhibited both methods on different trials. Nine $L$. exquisita larvae backed at least once, and seven of these entered headfirst on other trials. Similarly, the three $L$. candida larvae that exhibited backing all entered by the head-first method on other trials. Whenever $L$. piffardii entered head-first, the larvae showed the behaviour pattern for backing prior to the head-first entry on that trial. Among the L. pavida, all larvae backed at least once, but two of them also made head-first entries.

\section{Discussion}

It should be emphasized that under the conditions of the testing procedure, the case was the 
Table II. The Incidence of Backing as the Method of Case Entry in the Genus Leptocella

\begin{tabular}{lccccc}
\hline \multicolumn{1}{c}{ Species } & $\begin{array}{c}\text { No. } \\
\text { of } \\
\text { larvae }\end{array}$ & $\begin{array}{c}\text { Total } \\
\text { no. of } \\
\text { tests }\end{array}$ & $\begin{array}{c}\text { No. of } \\
\text { entries }\end{array}$ & $\begin{array}{c}\% \text { of } \\
\text { entries } \\
\text { occurring } \\
\text { by backing }\end{array}$ & $\begin{array}{c}\text { No. of } \\
\text { different } \\
\text { larvae that } \\
\text { backed }\end{array}$ \\
\hline L. diarina & 10 & 20 & 20 & 100 & 10 \\
L. albida & 4 & 11 & 10 & 90 & 4 \\
L. pavida & 12 & 24 & 16 & $87 \cdot 5$ & 12 \\
L. piffardii (?) & 8 & 22 & 20 & 70 & $7 *$ \\
L. candida & 6 & 13 & 13 & 31 & 3 \\
L. exquisita & 19 & 55 & 52 & 25 & 9 \\
L. species a (?) & 1 & 4 & 4 & 0 & 0 \\
\hline
\end{tabular}

*8th larva was damaged during eviction for 2nd test, therefore it had only one trial.

only object present to which the larva could cling. This probably reduced larval wandering to a minimum. Larvae often clung to their cases with their metathoracic legs while reaching out with their anterior ones. When only the glass floor and walls of the container were encountered with the legs, the animals often reversed themselves and crawled back along the case. If other materials had been present in the container, probably contact with the case would have been lost more readily, and more building activity would have occurred. In fact, an early procedure of placing sand in the bottom of the testing container was abandoned because of building activity.

It seems probable, then, that when the only alternative to contact with the case is wandering on a substrate which provides no foothold, the larva should exhibit whatever capacity it may have for case recognition.

The fact that recognition exists in all ten families tested suggests that case recognition is a primitive trait which presumably is associated with case-building behaviour and the need for covering the body - what Alverdes (1925) termed the Schutzinstinkt. In the Glossosomatidae, the most primitive of the case-building families (Ross 1964), this need apparently exists only in turbulent water, since in still water the larvae readily left their cases and wandered about naked. This tendency toward nakedness under some conditions supports the close relationship of this family to the free-living Rhyacophilidaea relationship which earlier classifications indicated by making Glossosomatidae a subfamily of the latter group (Betten 1934; Ross 1944).
Although the hydroptilid family as a whole is found in a variety of conditions (Ross 1944), the larvae used in this study were taken from a rapid stream. None of these left their cases in still water, and all re-entered them readily. Thus, to the extent that this small sample is representative, the occupancy of cases seems to be well established in this still primitive stage in the evolution of case-building, as well as in the large superfamily Limnephiloidea, or tubc-case builders, which contains the remainder of the case-building Trichoptera (Ross 1967).

Of the eight Limnephiloidea families tested, only the Phryganeidae appear to retain a good capacity for case recognition in all the species observed. In other families we find this capacity reduced to varying degrees down to a complete lack of recognition in a few species. The variation among individuals within a species, seen, for example, in Lepidostoma and Brachycentrus, suggests the possibility that genetic factors may be involved in the recognition response.

If case recognition is indeed a primitive behaviour trait that has been partially or even totally lost in certain species, there may be no selective advantage in these forms for the possession of such a trait. Since the case is thought to provide protection against predators (Davis 1934), there seems little doubt that occupancy of a case is to the animal's advantage. One might therefore suggest that many larvae never leave their cases and hence have no need for the capacity to re-enter them.

The literature provides some support for this suggestion. References to larvae leaving their cases are few, and generally involve species that 
show good case recognition. Lloyd (1921) reported that naked Neuronia (=Ptilostomis) larvae could be seen through the ice in the winter, and believed that the number of empty cases encountered during collecting was further evidence that these animals leave their cases readily. Davis (1934) described the capture and immobilization of the cases of young Ptilostomis larvae in a Hydropsyche net and the subsequent abandonment of the cases. Yphria californica larvae abandon their cases very readily when disturbed by collecting procedures (Wiggins 1962), and the present author has had similar experience in collecting other phryganeid larvae. Tindall (1960) reported that Triaenodes bicolor larvae, in reaching along the outside of the case, sometimes left the tube entirely, and subsequently re-entered head-first.

Reports on species whose case recognition appears less reliable include Limnephilus indivisus whose larvae abandoned their cases when the materials that were incorporated into them contributed so much buoyancy that the cases floated to the surface (Simpson 1903). When a Molanna angustata case was placed upside down in a situation where the larva was unable to gain a purchase on the substrate for righting itself, the larva eventually abandoned the case (Dembowski 1933). Cummins (personal communication) reported seeing naked Pycnopsyche larvae on the bank of a stream whose water level had recently receded after flooding. Apparently the larvae had been left in pools on the banks as the water receded, and abandoned their cases when the pools dried up.

In the three instances of case abandonment just cited, the larvae were in situations where the cases they were occupying had become a liability to them because of their positions. In such circumstances there would be no advantage in being able to re-enter the case, but rather in the ability to build a new case quickly.

One further point can be noted regarding differences between the phryganeids and most of the other tube-builders. The posterior end of the phryganeid case is typically wide open, permitting access at either end not only to the occupant but also to intruders. An easy way of demonstrating the readiness with which a phryganeid leaves its case is to place a naked larva in a container with an occupied case. As the naked animal enters the posterior end, the original occupant leaves via the front end, crawls along the outside of the case, and reenters at the posterior end to evict the intruder- who then repeats the action of the original occupant, etc. (Lloyd 1921). The situation often reminds observers of the game 'musical chairs'.

In contrast, most of the other tube-builders have a much narrower opening at the posterior end, either because the case is markedly tapered from front to back or because of structures built there by the larva (Rousseau 1921). Thus these larvae are unlikely to be attacked from the rear and driven from their cases. Even after removal of these posterior structures, the larvae usually offered great resistance to eviction in these experiments, thus giving further support to the idea that they do not readily leave their cases.

The occurrence of backing in only two genera probably represents parallel evolution, since the two genera are in different families, one of which contains several other genera not showing the trait.

Alverdes (1925) compared the head-first entry of Limnephilus larvae with the backing method by which a hermit crab enters a new shell, and felt that the head-first method was an appropriate adaptation for an animal with an armoured head and membranous posterior end. This point of view makes the assumption that the case being entered may be already occupied by some other animal. On the other hand, the animal which backs into its case has eliminated the necessity for turning around after enteringa process that is generally time-consuming and leaves the animal quite vulnerable at the anterior end of the case until it is completed. Moreover, it seems likely that the investigation of the mouth of the case before backing would reveal any occupant large enough to cause damage to a caddis larva.

If one assumes that backing is a superior method for entering a case, then the fact that it exists in so few forms is probably further evidence that circumstances requiring a larva to re-enter a case are indeed very rare.

The work reported here does not permit a definite conclusion regarding the nature of the recognition response. If we could demonstrate case recognition in newly hatched larvae that have not yet built cases, we could conclude that the behaviour pattern is unlearned. Once the larva has built a case, the possibility of learning exists. It is impossible at this point to know how much the learning process has contributed to the recognition responses. The varying capacities for case recognition may simply represent variations in the opportunity and/or the learning 
ability to associate the exterior of the case, as detected by legs and mouthparts, with the sheltered condition of the body.

Plans are in progress for testing newly hatched phryganeid larvae for case recognition.

\section{Summary}

Twenty-four genera representing ten families of case-building caddis larvae were tested for their capacity to recognize and re-enter their cases following eviction from them. Glossosomatidae entered cases readily only under conditions of turbulence, which was the only condition under which they tended to remain in their cases. A small sample of Hydroptilidae showed excellent case recognition. In eight families of tube-case builders, some degree of recognition was present in all, but only the Phryganeidae consistently showed good recognition and rapid entry. Entry by backing occurred in two genera of different families.

It is suggested that case recognition is a primitive trait which has been reduced or lost in several species. The trait is probably unnecessary in these species because the larvae rarely leave their cases.

\section{Acknowledgments}

Portions of this work were supported by Grants GU-816 and GE-8123 from the National Science Foundation. Funds from Smith College supported the summer work in 1966. Dr Glenn B. Wiggins kindly assisted in identification of reared adults. I am grateful to Dr B. Elizabeth Horner for a critical reading of the manuscript.

\section{R E F E R E N C E S}

Alverdes, F. (1925). Der Schutzintinkt der Köcherfliegenlarve. Biol. $Z l$. $45,149-154$.

Balduf, W. V. (1939). The Bionomics of Entomophagous Insects, Part II. St Louis: John S. Swift Co. Inc.

Betten, C. (1934). The caddis flies or Trichoptera of New York State. Bull. N.Y. State Mus., 292, 1-576.
Davis, M. B. (1934). Habits of the Trichoptera. Bull. N.Y. St. Mus., 292, 82-106.

Dembowski, J. (1933). Über der Plastizität der tierischen handlungen. Beobachtungen und Versuche an Molanna-larven. Zool. Jh., Abt. Allg. Zool., 53, 261-312.

Flint, O. S. (1960). Taxonomy and biology of nearctic limnephilid larvae with special reference to species in eastern United States. Entomologiea Am., 50 (N.S.), 1-117.

Lloyd, J. T. (1921). Biology of North American caddisfly larvae. Lloyd Libr. of Bot., Pharm., and Mat. Med., Entomol. Ser., 1, 1-124.

Merrill, D. (1964). An analysis of case recognition and case building bchavior in four species of Trichopteran larvae. Ph.D. dissertation, Univ. of Michigan, Ann Arbor.

Merrill, D., \& Shaw, P. R. (1966). Case recognition in caddis-worms. Am. Zool., 6, 297 (Abstract).

Merrill, D. \& Shaw, P. R. (1967). The behavior of caddisworms. Part I: The animal in its case. Bull. ecol. Soc. Am., 48, 67-68 (Abstract).

Ross, H. H. (1944). The caddis flies or Trichoptera of Illinois. Bull. Ill. Nat. Hist. Surv., 23, 1-326.

Ross, H. H., (1964). Evolution of caddis worm cases and nets. Am. Zool., 4, 209-220.

Ross, H. H. (1967). The evolution and past dispersal of the Trichoptera. A. Rev. Ent., 12, 169-206.

Rousseau, E. (1921). Les Larves et Nymphes Aquatiques des Insectes d'Europe. Brussels: J. Lebegue \& Co.

Simpson, C. B. (1903). The log-cabin builder (Limnophilus indivisus Walker). Proc. ent. Soc. Wash., 5, 98-100.

Tindall, A. R. (1960). The larval case of Triaenodes bicolor Curtis (Trichoptera: Leptoceridae). Proc. R. ent. Soc. Lond., 35, 93-96.

Wesenberg-Lund, C. J. (1911). Über die Biologie der Phryganea grandis und über die Mechanik ihres Gehäusebaues. Int. Revue ges. Hydrobiol. Hydrogr, 4, 65-90.

Wiggins, G. B. (1960). A preliminary systematic survey of the North American larvae of the caddis fly family Phryganeidae (Trichoptera). Can. J. Zool., 38, 1153-1170.

Wiggins, G. B. (1962). A new subfamily of phryganeid caddis flies from western North America (Trichoptera: Phryganeidae). Can. J. Zool., 40, 879-891.

(Received 7 September 1968; revised 3 November 1968; Ms. number: A746) 